\title{
STRATEGI PENGEMBANGAN DAN BAURAN PEMASARAN POTENSI KOMODITAS KOPI DALAM RANGKA PENGUATAN PASAR PRODUK PERTANIAN SECARA INTEGRATIF DENGAN SEKTOR PARIWISATA DI KABUPATEN BANYUWANGI
}

\author{
Dimas Imaniar ${ }^{1}$ ) Andhika Wahyudiono ${ }^{2}$ ) \\ 1) Ilmu Administrasi, Universitas 17 Agustus 1945 Banyuwangi e-mail:dimasimaniars@gmail.com \\ 2) Ilmu Ekonomi, Universitas 17 Agustus 1945 Banyuwangi e-mail: andhikaw@gmail.com
}

\begin{abstract}
The one of commodities that contribute economies in agricultural sector, has an integrated competitiveness and agribusiness that can improve the welfare of the famers is coffee. This research aims to find out; Formulating development strategy on coffee commodities in order to strengthen agricultural product market in integrative with tourism sector in Banyuwangi Regency. The research area is determined purposively, that is in Banyuwangi Regency. This research uses descriptive and analytic method. Sampling method is conducted purposively (purposive sampling). This research is analyzed using Location Quotient, Marketing Mix and Force Field Analysis tools. The research results show that by formulation of strategy model of development of coffee commodities in order to strengthen agricultural product market in integrative with tourism sector in Banyuwangi Regency which can be used on of the government policy and provide better life expectancy of coffee farmers.
\end{abstract}

Keywords: Agriculture sector, coffee, Location Quotient analysis, marketing mix, intregation, tourism sector, strategy and development model

\begin{abstract}
Abstrak
Salah satu komoditas yang memberikan sumbangan perekonomian yang diperhitungan di sektor pertanian peningkatan daya saing dan agribisnis terpadu yang dapat memperbaiki kesejahteraan keluarga pekebun, salah satunya adalah komoditas kopi. Penelitian ini bertujuan untuk merumuskan strategi pengembangan komoditas kopi dalam rangka penguatan pasar produk pertanian yang integratif dengan sektor pariwisata di Kabupaten Banyuwangi. Penentuan daerah penelitian ditentukan secara sengaja (purposive method). Penelitian ini menggunakan metode deskriptif dan analitik. Metode pengambilan contoh dilakukan secara sengaja (purposive sampling). Penelitian ini dianalisis menggunakan alat analisis wilayah (Location Quotient) bauran pemasaran dan medan kekuatan (Force Field Analysis). Hasil penelitian ini adalah sebuah model model strategi pengembangan komoditas kopi dalam rangka penguatan pasar produk pertanian yang integratif dengan sektor pariwisata di Kabupaten Banyuwangi yang nantinya dapat dijadikan salah satu pedoman pembuatan kebijakan pemerintah daerah Kabupaten Banyuwangi dan dapat memberikan harapan kehidupan yang lebih baik bagi petani kopi.
\end{abstract}

Kata kunci: Sektor pertanian, kopi, analisis wilayah, bauran pemasaran, integrasi, sektor pariwisata, strategi pengembangan. 


\section{PENDAHULUAN}

Pengembangan wisata berbasis perkebunan kopi mulai tampak di Lingkungan Lerek, Gombengsari, dan Kalipuro yang berjarak 14 kilometer dari pusat kota Banyuwangi. Sejumlah petani kopi mulai merintis rumah singgah (home stay) di perkebunan kopi miliknya. Tidak hanya disuguhi lanskap kebun kopi, wisatawan akan disuguhi pengalaman merawat tanaman kopi, memanen, dan mengolah hingga menyajikan serta menikmati sendiri kopi racikannya. Sehingga melalui pemenuhan permintaan masyarakat terhadap komoditas kopi maka secara tidak langsung memberikan nilai tambah pada komoditas kopi dan juga memberikan dampak yang positif bagi tingkat kesejahteraan petani kopi di Kelurahan Gombengsari Kecamatan Kalipuro dan sekitarnya.

Sementara tingginya minat masyarakat terhadap permintaan kopi di Kabupaten Banyuwangi seiring dengan tumbuhnya sektor pariwisata, maka akan lebih baik jika petani kopi di Kelurahan Gombengsari memperhatikan dari segi potensi produksinya. Apabila produksi kopi dapat menyuplai di wilayah sendiri maka perlu memperhatikan kondisi bauran pemasaran agar tetap dipertahankan kondisi pemasarannya karena suatu produk dapat tersalurkan dengan baik kepada konsumen dan bisa memperoleh keuntungan yang maksimal apabila kondisi pemasasarannya baik. Ketika potensi produksi dan kondisi bauran pemasaran kopi di wilayah Kelurahan Gombengsari dapat diketahui dan diperhatikan, maka dapat disesuaikan sebuah strategi untuk pengembangan kopi dalam rangka penguatan pasar produk pertanian yang integratif dengan sektor pariwisata di Kabupaten Banyuwangi berdasarkan pada faktor pendorong dan faktor penghambat dalam usahatani kopi di Kelurahan Gombengsari sehingga potensi kopi di Kelurahan Gombengsari dapat memberikan manfaat positif bagi masyarakat petani di wilayah tersebut. Berdasarakan pada fenomena tersebut, maka dapat dirumuskan identifikasi masalah dalam kajian ini adalah mengenai kondisi potensi produksi kopi di Kelurahan Gombengsari Kecamatan Kalipuro Kabupaten Banyuwangi. Dengan demikian tujuan dari kajian ini adalah: (1) Menganalisis dan mendeskripsikan potensi produksi kopi di Kecamatan Kalipuro;

Mengidentifikasi dan mendeskripsikan kondisi bauran pemasaran komoditas kopi di Kelurahan Gombengsari 
Dimas \& Andhika, strategi pengembangan dan bauran pemasaran potensi komoditas kopi dalam rangka penguatan pasar produk ...

Kecamatan Kalipuro; dan (3)

Mengidentifikasi serta mendeskripsikan faktor pendorong dan faktor penghambat dalam usahatani kopi di Kelurahan Gombengsari.

\section{METODOLOGI PENELITIAN}

Pendekatan penelitian dilakukan melalui pendekatan deskriptif dan analitik. Pengambilan Lokasi Penelitian dengan purposive methode yang berlokasi di Kelurahan Gombengsari Kabupaten Banyuwangi, dengan jangka waktu 3 (tiga) bulan. Teknik Pengambilan data dilakukan dengan metode wawancara mendalam (Brainstorming), FGD dan observasi. Pengambilan sampel dilakukan dengan teknik Snowball Sampling. Data yang digunakan adalah data primer dan data sekunder. Metode analisis analisa data meliputi: (1) Analisis LQ; (2) Analisis Bauran Pemasaran; dan (4) Analisis medan kekuatan.

\section{HASIL DAN PEMBAHASAN}

1. Potensi Komoditas Kopi di Kecamatan Kalipuro Kabupaten Banyuwangi

Perhitungan Analisis Location Quotient (LQ) dilakukan dengan menggunakan indikator jumlah produksi tanaman perkebunan dengan jumlah produksi total di masing-masing wilayah kecamatan yang ada di Kabupaten Banyuwangi. Analisis yang dilakukan dalam kajian ini merupakan kajian terhadap nilai LQ selama kurun waktu lima tahun terhitung mulai tahun 2013 sampai tahun 2017. Analisis Location Quotient (LQ) juga dapat digunakan untuk mengetahui besarnya peranan suatu sektor di suatu daerah terhadap besarnya peranan sektor tersebut secara menyeluruh. Melalui analisis Location Quotient (LQ) komoditas tanaman perkebunan di Kabupaten Banyuwangi, dapat diketahui apakah komoditas tanaman perkebunan akan memberikan suatu gambaran arah pengembangan bagi wilayah Kabupaten Banyuwangi, khususnya dalam hal mengoptimalkan keunggulan wilayah baik dari segi sumberdaya alam maupun sumberdaya manusia. Kabupaten Banyuwangi memiliki perkebunan yang mampu menunjang perekonomian di bidang pertanian. Melalui analisis LQ dapat diketahui bahwa di Kecamatan Kalipuro, tanaman kopi memiliki ratarata nilai LQ yang diperoleh dari hasil analsis adalah sebesar 1,30. Nilai dari hasil analisis LQ tersebut menandakan bahwa komoditas kopi di Kecamatan Kalipuro adalah komoditas basis yang 
mampu mememenuhi kebutuhan pasar atau permintaan kopi di wilayah Kecamatan Kalipuro dan memiliki kemampuan pula untuk mengirim kopi ke luar wilayah Kecamatan Kalipuro.

Salah satu wilayah di dalam Kecamatan Kalipuro yang telah memiliki keunggulan kompetitif dan komparatif dalam pengembangan pertanian perkebunan kopi adalah di wilayah Kelurahan Gombengsari. Keunggulan tersebut didukung dengan adanya luas lahan perkebunan rakyat di Kelurahan Gombengsari seluas 850 hektar dengan rata-rata produksi setiap hektar sebesar 2,7 sampai 3 ton. Luasan lahan dengan jumlah produksi tersebut merupakan nilai yang dihasilkan selama berproses selama bertahun-tahun dimana masyarakat petani kopi di Kelurahan Gombengsari selalu memiliki semangat dalam memperbaiki potensi tanaman kopi agar kualitas dan kuantitasnya meningkat dan layak untuk bersaing di pasaran. Masyarakat petani kopi di Kelurahan Gombengsari tidak hanya memproduksi kopi dalam bentuk gelondongan saja tetapi juga dalam bentuk bubuk. Hal ini ditekankan agar seluruh masyarakat petani yang tergabung dalam kelompok tani di

Kelurahan Gombengsari mampu menghasilkan kopi dalam bentuk bubuk.
Karena dengan menghasilkan kopi dalam bentuk bubuk akan dapat memberikan nilai tambah pada komoditas kopi sehingga dapat membantu masyarakat petani kopi untuk meningkatkan pendapatannya dalam subsektor perkebunan, selain itu pula dengan diversifikasi produk, maka akan dapat memberikan efek ganda yang positif kepada masyarakat sekitar.

Jenis kopi yang terdapat di Kelurahan Gombengsari adalah Kopi Robusta sebagai kopi induk yang mayoritas ditanam di hamparan lahan petani. Kopi Robusta yang ditanam di Kelurahan Gombengsari juga terdapat beberapa jenis yang menurut petani berbeda cita rasanya, antara lain Kopi Robusta Lanang, Tlogosari, Konoga dan Kleres. Untuk memperoleh pendapatan yang tinggi petani kopi juga melaksanakan berbagai kegiatan dengan mengembangkan berbagai kemungkinan komoditi kopi dengan jenis lain yang secara ekonomis menguntungkan jika lahan pertanian yang dimiliki memungkinkan. Adapun cara yang dilakukan adalah di setiap sela tanaman Kopi Robusta pada hamparan lahan juga ditanami beberapa jenis kopi seperti Kopi Arabika dan Excelsa. 
Dimas \& Andhika, strategi pengembangan dan bauran pemasaran potensi komoditas kopi dalam rangka penguatan pasar produk ...

2. Bauran Pemasaran Komoditas Kopi dalam Rangka Penguatan Pasar Produk Pertanian yang Integratif dengan Sektor Pariwisata di Kabupaten Banyuwangi

Pada kajian penelitian ini, potensi kopi di Kelurahan Gombengsari potensial untuk dikembangkan karena memiliki nilai basis. Sehingga ketika sebuah komoditas atau produk memiliki potensi untuk dikembangkan dari segi produksi, maka langkah tepat selanjutnya adalah melakukan penetapan strategi dalam bauran pemasaran. Masyarakat petani kopi di Kelurahan Gombengsari tergabung dalam beberapa kelompok tani dan beberapa kelompok tani tersebut memiliki beberapa produk hasil olahan buah kopi menjadi kopi bubuk. Setiap anggota kelompok tani yang ada di Kelurahan Gombengsari selalu berupaya bagaimana membuat sebuah produk yang memiliki nilai jual tinggi dipasaran agar produk yang dihasilkan mampu menarik minat masyarakat, sehingga ketika sebuah produk memiliki nilai jual yang tinggi, tentu akan berdampak positif terhadap yang dinlai dari beberapa indikator. Upaya yang dilakukan oleh masyarakat petani kopi tersebut dirumuskan menjadi suatu strategi yang disebut sebagai bauran pemasaran. Bauran pemasaran merupakan sebuah rumusan strategi yang mencakup mengenai bagaimana sebuah produk bisa diterima masyarakat, harga yang melekat pada produk, tempat penjualan produk dan cara promosi agar produk tersebut memiliki nilai lebih bagi masyarakat sehingga masyarakat tertarik untuk mengkonsumsinya. Berikut beberapa indikator yang dirumuskan dalam strategi bauran pemasaran:

\section{Product (Produk)}

Produk merupakan elemen dasar yang utama dalam sebuah pemasaran, karena sebuah sistem pemasaran tidak akan berjalan baik apabila tidak ada produk yang diperjualbelikan. Produk terdiri dari barang dan jasa, melalui produk yang dihasilkan oleh seorang produsen, maka nilai manfaat yang melekat pada sebuah produk dapat dirasakan manfaatnya oleh konsumen. Pada kajian penelitian ini, sasaran produk yang diteliti adalah bahan baku kopi. Kopi merupakan komoditas yang usahataninya merupakan mata pencaharian utama bagi masyarakat petani yang ada di Kelurahan Gombengsari. Jenis kopi yang ditanam di Kelurahan Gombengsari sebagai indukan adalah kopi robusta. Sementara kopi robusta di wilayah 
Gombengsari masih terbagi menjadi beberapa jenis antar lain Konoga, Lanang, Kleres dan Tlogosari. Selain Kopi Robusta, terdapat beberapa jenis kopi lainnya yang ditanam oleh masyarakat petani Gombengsari yaitu Arabika dan Excelsa, akan tetapi jenis kopi Arabika dan Excelsa tidak memiliki hamparan lahan yang luas, hanya saja dalam satu hamparan luas kopi Robusta, maka terdapat jenis tanaman kopi ARabika dan Excelsa beberapa pohon saja. Semua jenis kopi yang ditanam di wilayah Gombengsari diolah dan diperjualbelikan oleh masyarakat petani kopi dalam bentuk gelondongan atau ose dan dalam bentuk bubuk.

Nilai manfaat kopi bubuk lebih besar daripada kopi ose, akan tetapi bukan berarti kopi ose tidak ada peminatnya. Jenis kopi bubuk tidak dihasilkan oleh semua masyarakat petani atau kelompok tani, hanya terdapat beberapa kelompok saja yang mengolah biji kopi dalam bentuk bubuk. Hal ini dikarenakan untuk modal yang dibutuhan dalam bentuk materi dan non materi tidak cukup dimiliki oleh sebagian masyarakat dalam kelompok tani. Sehingga masih ada beberapa

\begin{abstract}
kelompok yang hanya memperjualbelikan kopi Gombengsari dalam bentuk gelondongan saja. Perbedaan jenis kopi tentu juga mempengaruhi cita rasa dari kopi yang dihasilkan, secara umum cita rasa kopi di wilayah Gombengsari memiliki kekhasan tersendiri karena kopi di wilayah Gombengsari ditanam diantara wialayah pegunungan dan lautan. Sementara untuk masingmasing jenis kopi yang ditanam seperti robusta memiliki cita rasa yang soft, berbeda dengan kopi jenis arabika yang memiliki rasa cenderung asam dan kuat dan untuk jenis kopi Excelsa memiliki rasa perpaduan asam yang tidak begitu tinggi seperti arabika dan juga cenderung kuat.
\end{abstract}

\section{Price (Harga)}

Harga merupakan komponen yang melekat pada sebuah produk, ketika sebuah produk tercipta, maka akan memiliki nilai tambah berdasarkan harga di setiap produknya. Pembentukan sebuah harga tidak sekedar diputuskan begitu saja akan tetapi minimal berdasarkan perhitungan jumlah biaya yang telah dikeluarkan dalam menciptakan sebuah produk yang 
Dimas \& Andhika, strategi pengembangan dan bauran pemasaran potensi komoditas kopi dalam rangka penguatan pasar produk...

bersangkutan sehingga harga jual yang ditentukan diharuskan melebihi biaya produksi. Hal tersebut dimaksudkan agar para produsen dapat memperoleh manfaat dari penciptaan sebuah produk hingga poses terebut berulang.

Harga yang melekat pada kopi di wilayah Gombengsari tidak semua sama, akan tetapi disesuaikan dengan jenisnya. Harga kopi bubuk jauh lebih besar dibandingkan harga kopi gelondongan. Harga kopi bubuk per kilogram rata-rata Rp. 80.000 sampai dengan Rp. 150.000. Sementara untuk harga kopi ose atau gelondongan rata-rata harga yang ditawarkan oleh petani antara Rp. 25.000 sampai dengan Rp. 50.000 per kilogram. Perbedaan harga yang diberikan oleh petani ditentukan pula berdasarkan jenis kopi yang ditanam oleh petani di wilayah Gombengsari.

\section{Place (Tempat)}

Pada bauran pemasaran, setelah produk dan harga, yang harus diperhatikan selanjutnya adalah kondisi tempat. suatu tempat yang digunakan untuk melakukan berbagai kegiatan perusahaan untuk membuat produk dan produk tersebut dapat di peroleh dan tersedia bagi pelanggan sasaran, yaitu dengan menyediakan saluran pemasaran, cakupan pasar, pengelompokan, lokasi, persediaan,transportasi. Saluran pemasaran yang terdapat pada pemasaran kopi di Wilayah Gombengsari secara keseluruhan para konsumen mengambil secara langsung ke petani kopi. Terkadang pula para petani kopi juga memasarkan produknya, yaitu dengan melakukan kemitraan dengan beberapa outlet atau cafe yang menjual minuman kopi. Cakupan pasar kopi berada di wilayah Kabupaten Banyuwangi dan di luar Kabupaten Banyuwangi.

\section{Promotion (Promosi)}

Pada bauran pemasaran, promosi merupakan salah satu hal penting yang harus diperhatikan bagi seorang produsen. Melalui promosi maka sebuah produk akan sampai kepada konsumen. Pada kajian penelitian ini, promosi yang dilakukan oleh petani kopi adalah melalui beberapa aplikasi sosial media . selain itu promosi juga melalui kegiatan atau event pariwisata. Kegiatan wisata merupakan salah satu sarana yang 
potensial untuk mempromosikan produk kopi Gombengsari. Penetapan promosi pada produk kopi juga melalui penetapan harga. Para konsumen yang membeli produk kopi dalam jumlah kecil dan besar memiliki penetapan harga yang berbeda. Sehingga melalui promosi tersebut para konsumen berminat untuk membeli kopi dalam jumlah banyak. Packaging dari produk kopi juga sangat mempengaruhi tingkat minat konsumen. Beberapa kemasan produk kopi produksi Gombengsari memiliki kemasan yang menarik sehingga beberapa konsumen tertarik untuk membeli kopi tersebut.

Berdasarkan kondisi lapang, beberapa bauran pemasaran tersebut ditetapkan sesuai dengan kemampuan yang dapat dilakukan para petani kopi. Bauran pemasaran yang terdiri dari produk, harga, promosi, dan tempat memiliki faktor-faktor yang berbeda dalam setiap baurannya. Keseluruhan elemen tersebut didasari dari adanya tujuan pemasaran yakni memasyarakatkan kopi Gombengsari melalui sinergitas dengan kegiatan wisata, meningkatkan penjualan, dan meningkatkan citra usaha yang mana keseluruhan tujuan pemasaran tersebut memiliki goal untuk menentukan prioritas pemasaran Kopi Gombengsari.

\subsection{Strategi Pengembangan Komoditas Kopi dalam Rangka Penguatan Pasar Produk Pertanian yang Integratif dengan Sektor Pariwisata di Kabupaten Banyuwangi}

Strategi pengembangan usahatani kopi di Kelurahan Gombengsari dapat diketahui dengan menganalisis faktor pendorong dan penghambat menggunakan alat analisis yang bernama analisis medan kekuatan atau FFA (Force Field Analysis). FFA (Force Field Analysis) merupakan suatu alat analisis yang digunakan dalam merencanakan strategi lebih baik berdasarkan faktor pendorong dan penghambat, Hasil dari analisis FFA akan memunculkan strategi yang meminimalisasi faktor penghambat dengan mengoptimalkan faktor pendorong ke arah tujuan yang akan dicapai. Berdasarkan pada hasil wawancara secara mendalam (in-depth interview) dengan para expert (tim ahli), terdapat lima faktor pendorong dan lima faktor penghambat yang terdapat pada usahatani kopi di Kelurahan Gombengsari. Berikut tabel faktor pendorong dan faktor penghambat 
Dimas \& Andhika, strategi pengembangan dan bauran pemasaran potensi komoditas kopi dalam rangka penguatan pasar produk ...

usahatani kopi di Kelurahan

Gombengsari.

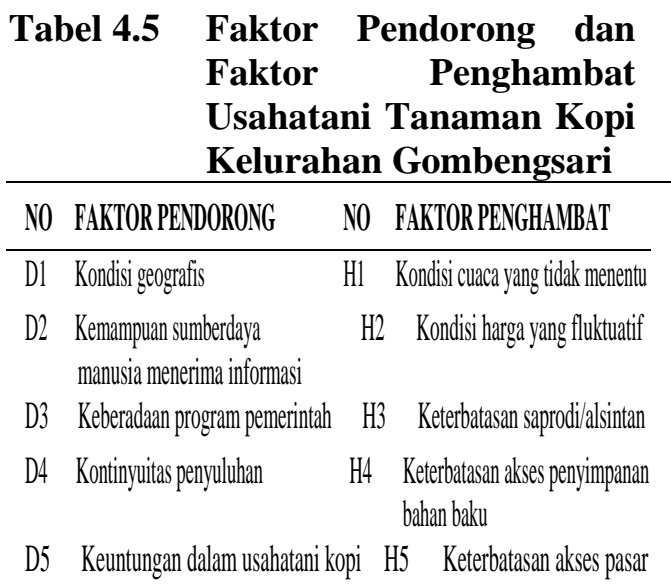

Sumber : Data Primer Diolah Tahun 2018

Faktor pendorong dan faktor penghambat tersebut nantinya akan ditentukan menjadi kekuatan kunci keberhasilan dalam Faktor Pendorong dan Faktor Penghambat usahatani kopi di Kelurahan Gombengsari. Diperlukan penyusunan strategi dalam pengembangan usahatani tanaman kopi yang harus memperhatikan kesesuaian arah optimalisasi pendorong kunci ke arah perbaikan penghambat kunci. Artinya jika pendorong kunci dan penghambat kunci yang dipilih lebih dari satu, maka penyusunan strategi harus memperhatikan kesesuaian perpaduan masing-masing faktor untuk menuju tujuan yang akan dicapai. Berdasarkan evaluasi diperoleh masingmasing satu pendorong kunci dan penghambat kunci. Strategi fokus yang diperoleh berdasarkan FKK pendorong dan FKK penghambat yang telah dipilih dengan cara menyinergikan antara beberapa pihak yang terkait dan dapat membantu perwujudan keberadaan usahatani tanaman kopi lebih kuat dan berkembang sehingga dapat mendukung sepenuhnya program pengembangan subsector perkebunan agar manfaatnya dapat dirasakan secara kontinyu. Pihakpihak tersebut terdiri dari masyarakat petani kopi di Kelurahan Gombengsari, Badan Perencanaan dan Pembangunan Daerah Kabupaten Banyuwangi, Dinas Pertanian Kabupaten Banyuwangi, Dinas Pariwisata, , Dinas Perindustrian dan Perdagangan Kabupaten Banyuwangi, Dinas Koperasi dan beberapa lembaga keuangan formal.

Melalui strategi tersebut, diharapkan bahwa stakeholder tetap memberikan dukungan aktif dan kontinyu dalam pengembangan usahatani tanaman kopi melalui kelembagaan yang ada dalam rangka mendukung program pengembangan subsektor perkebunan. Keberadaan para pelaku pada usahatani tanaman kopi di Kelurahan Gombengsari ditekankan pada keadaan dimana pihak tersebut saling terkait dan memberi manfaat satu 
sama lain dalam menguatkan kondisi usahatani kopi dengan tetap fokus pada peran yang telah ditetapkan, sehingga program pengembangan subsektor perkebunan yang nantinya bersinergi dengan subsector pariwisata memiliki manfaat yang dapat dirasakan secara kontinyu oleh para pelaku yang terlibat di dalam usahatani kopi dan tujuan dari adanya program dapat terealisasi secara optimal member dampak positif bagi semua kalangan di Kabupaten Banyuwangi.

\section{PENUTUP}

\section{Simpulan}

1. Potensi komoditas kopi di Kabupaten Banyuwangi merupakan komoditas basis yang sesuai dengan nilai hasil analisis Location Quotient (LQ) sebesar 1,30.

2. Bauran pemasaran kopi di Kelurahan Gombengsari ditetapkan sesuai dengan kemampuan yang dapat dilakukan para petani kopi. Bauran pemasaran yang terdiri dari produk, harga, promosi, dan tempat memiliki faktor-faktor yang berbeda dalam setiap baurannya.

3. Strategi fokus yang diperoleh berdasarkan pendorong dan penghambat yang telah dipilih dengan cara menyinergikan antara beberapa pihak yang terkait dan dapat membantu perwujudan keberadaan usahatani tanaman kopi lebih kuat dan berkembang sehingga dapat mendukung sepenuhnya program pengembangan subsector perkebunan agar manfaatnya dapat dirasakan secara kontinyu. Pihakpihak tersebut terdiri dari masyarakat petani kopi di Kelurahan Gombengsari, Badan Perencanaan dan Pembangunan Daerah Kabupaten Banyuwangi, Dinas Pertanian Kabupaten Banyuwangi, Dinas Pariwisata, , Dinas Perindustrian dan Perdagangan Kabupaten Banyuwangi, Dinas Koperasi dan beberapa lembaga keuangan formal

\section{Rekomendasi}

Dari hasil pembahasan dapat diberikan beberapa rekomendasi dalam rangka pengembangan komoditas kopi, sebagai berikut:

1. Bagi pemerintah daerah melalui dinas terkait dibutuhkan konsep pembinaan secara intensif dan bersinergi oleh semua pemangku kepentingan (pemerintah, BUMN, swasta, LSM, dll) dengan memberikan pelatihan teknis, manajemen usaha, kewirausahaan, 
Dimas \& Andhika, strategi pengembangan dan bauran pemasaran potensi komoditas kopi dalam rangka penguatan pasar produk ...

dan pinjaman modal sehingga wilayah penghasil komoditas unggulan tanpa mengabaikan komoditas non unggulan, dapat berkembang sebagai motor penggerak ekonomi masyarakat. Selain itu diharapkan untuk pihak dinas terkait untuk mematenkan data satu pintu melalui pemetaan data potensi

2. Bagi petani kopi, agar dapat dicapai hasil usahatani kopi yang optimal, maka beberapa hal yang dapat dilakukan antara lain (a) pengolahan lahan yang sesuai dengan kondisi setempat dan pemakaian bibit unggul; (b) meningkatkan efisiensi pemanfaatan lahan dapat dilakukan melalui pola pengaturan pertanaman bagi beberapa komoditas dalam satu lahan sehingga dapat meningkatkan pendapatan petani; (c) memanfaatkan sarana prasarana yang telah difasilitasi oleh pemerintah secara optimal.

3. Bagi masyarakat umum, agar hasil produksi di wilayah Kabupaten Banyuwangi memiliki nilai tambah yang dapat bersaing dengan wilayah lain, sebaiknya masyarakat memiliki kesadaran diri melalu pola konsumsi hasil produksi kopi wilayah sendiri, dengan begitu maka pola perputaran anggaran dapat dimanfaatkan oleh seluruh lapisan masyarakat di Kabupaten Banyuwangi.

\section{DAFTAR PUSTAKA}

AAK. (2008). Budidaya Tanaman Kopi. Yogyakarta: Kanisius

Ajisaka. (2009). Produksi Kopi Indonesia Masih Posisi Empat Dunia. http://radio.spin.net.id. (diakses 15 Februari 2018).

Arsyad, L. (2009). Ekonomi Pembangunan. Bagian Penerbitan Sekolah Tinggi Ilmu Ekonomi YKPN. Yogyakarta.

Bakri. 2010. Metodologi Penelitian Kualitatif Tinjauan Teoritis dan Praktis. Malang. Lembaga Penelitian Universitas Islam Malang.

Direktorat Jenderal Perkebunan. (2015). Rencana Strategis Direktorat Jenderal Perkebunan Tahun 2015-2019. Jakarta: Kementerian Pertanian

Hariono. (2017). Pariwisata menjadi Sarana Promosi Kopi. https://www.pressreader.com/ indonesia/kompas/.(diakses 18 Februari 2018)

Hurriyati, Ratih. 2010. Bauran Pemasaran dan Loyalitas Konsumen : Fokus Pada Konsumen Kartu Kredit Perbankan. Bandung : Penerbit CV.Alfabeta. 
Kotler, P., and Armstrong, G. (2011). Prinsip-Pronsip Pemasaran. Jakarta: Erlangga.

Najiyati, S. dan Danarti.( 2010). Kopi: Budidaya dan Penanganan Lepas Panen. Jakarta: Penebar Swadaya.

Hermanto, Fadholi. (2009). Ilmu Usahatani. Jakarta: Penebar Swadaya.

Dinas Perkebunan Jawa Timur. (2014). Rencana Strategis 2012-2019. https://disbun.jatimprov.go.id/RE NSTRA20142019.pdf. (diakses 15 Februari 2018)

Pahan, Iyung. (2008), Panduan Lengkap Kelapa Sawit Manajemen Agribisnis dari Hulu hingga Hilir. Cetakan 6, Jakarta: Penebar swadaya.

Puslitbangbun. (2015). Tanaman Kopi. Perkebunan. litbang.go.id. (diakses 17 Februari 2018)

Saputra, E. 2008. Kopi dan Sejarah Efek bagi Kesehatan Tubuh dan Gaya Hidup. Yogyakarta: Harmoni Panembahan.

Sianipar dan Entang. 2010. Teknikteknik Analisis Manajemen. Jakarta : Lembaga Administrasi Negara RI.

Soetriono, dkk. 2013. Akselerasi Inovasi Teknologi Pasca Panen Berbasis Komoditas Kopi Dan Kakao. Jember. Lembaga Penelitian Universitas Jember.

Soetriono. (2008). Daya Saing Pertanian Dalam Tinjauan Analisis. Bayumedia. Malang.

Sugiyono. 2010. Metode Penelitian Pendidikan Pendekatan Kuantitatif, kualitatif, dan $R \& D$. Bandung: Alfabeta.

Swastha B, Irawan. 2009. Manajemen Pemasaran Modern. Yogyakarta (ID): Liberty Yogyakarta.
Tarigan, Robinson.( 2009). Ekonomi Regional Teori dan Apikasi. Bumi Perkasa. Jakarta

Tjiptono, Fandy, (2008). Strategi Pemasaran. Edisi Ke-3. Penerbit Andi. Yogyakarta.

Tjiptono, Fandy dan Gregorius, Chandra.(2012). Pemasaran Strategik . Edisi 2. Penerbit Andi. Yogyakarta.

Husein, Umar. 2008. Metode Penelitian Untuk Skripsi dan Tesis Bisnis. Jakarta. PT Rajagrafindo Persada

Wibowo.R. (2008). Revitalisasi Komoditas Unggulan Perkebunan Jawa Timur. Jakarta: Perhepi

Zainal. (2011). Pengembangan Agribisnis Seraiwangi Berwawasan Konservasi di Kota Sawahlunto. Sumatra Barat: Puslitbangbun Pemkot Sawahlunto.

Wijaya, T. (2011). Manajemen Kualitas Jasa. Edisi 1.Indeks. Jakarta. 